\title{
11 France and the archives of the Algerian War
}

\author{
Gilles Manceron and Gilles Morin
}

In France, the National Archives were founded in September 1790, following adoption of the Declaration of the Rights of Man in 1789. The principle of freedom of access to archives for all citizens was also confirmed. ${ }^{2}$ It was officially declared that the archives of all state agencies and public authorities belonged to the nation and not to the organizations or authorities that produced them, that all citizens were entitled to consult these records and that the role of archives was not to act as custodians of state secrets but to enable citizens to consult documents retracing their history without impediment.

But it was not long before this fine principle was flouted. In 1800, responsibility for archives was transferred to the Ministry of the Interior and, when the First French Empire (1804-1815) was established under Napoleon Bonaparte, they became the "imperial archives" and, on 6 May 1812, an official order was issued banning access to archival catalogues. Under the monarchies that followed (1815-1848), the "archives of the kingdom" remained the property of the rulers and their administrations. A statutory period of 50 years was set during which documents would not be available for consultation. It was not until 1846 that readers were entitled to have access to original documents, and until 1850, under the Second Republic, that the first reading room was opened. During the Second Empire (1852-1870), the "imperial archives” remained under the Emperor's authority.

\section{Archives under state control}

With the advent of the Third Republic in the 1870s, the National Archives stayed under state control via the Ministry of Public Instruction, which used them to compile the "History of France", an account to be related in classrooms to foster national solidarity. The ministerial order of 16 May 1887 also set a minimum statutory closure period of 50 years, a principle that still applies today, ${ }^{3}$ although the length of this period was later modulated under different laws and in relation to different categories of archive.

Some ministries and authorities, such as the Ministry of Foreign Affairs, the Ministry of War, the Ministry of the Colonies, the Council of State and the 
Seine département police headquarters (which later became the Paris police headquarters), refused to comply with the legal requirement to transfer their records to the National Archives and continued to keep their own records. Following an unsuccessful attempt to drive through a law on archives, the government of the Popular Front bowed to circumstances in a decree dated 21 July 1936, Article 3 of which authorised authorities not having met the legal transfer requirement to maintain their own archives, provided they did so "within the framework of the law". This begs the question of why and for how long these authorities should continue to enjoy exemption from the transfer requirement in this way. For example, what real justification is there for letting the army manage its own historical archives - those that have existed for more than 50 years - when these are not "current archives"? Because these records are managed separately, how is it possible to be certain that they are being kept within "the framework of the law"? Even when government employees from France's National Archives are appointed to the Defence Historical Service (SHD - Service Historique de la Défense), the army continues to be ultimately responsible for the records held by the SHD. The French armed forces form a sort of "memory enclave" within the Republic. To make matters worse, in 2011 towards the end of Nicolas Sarkozy's presidency, not only was a general interministerial instruction (Instruction générale interministerielle [IGI] 1300) issued but, in addition, in late 2019, the armed forces were empowered to halt access to documents produced under their authority, irrespective of when they were issued or where they were stored (at the SHD, National Archives or elsewhere). They continue, after a fashion, to enjoy the "right to manage their own history", even though this is an integral part of French history and their archives (with the exception of recent documents containing current information of a sensitive nature relating to national security) should be accessible to the population as a whole.

\section{“Giscard” Law of 3 January 1979}

In 1959, under the Fifth Republic, responsibility for the National Archives was transferred from the Ministry of Primary and Secondary Education to the Ministry of Cultural Affairs. The law on archives of 3 January 1979 was adopted during Valéry Giscard d'Estaing's term as President (1974-1981). Article 33 refers officially to the abrogation of three laws dating from the French revolution. ${ }^{4}$ Yet it would be an exaggeration to say that this made archives and records even less accessible. Shortly before, the law of 17 July 1978 on "freedom of access to official documents" placed limits on the degree of secrecy that the authorities could exercise over documents concerning their citizens. Until then, the principle of secrecy had always applied in contradiction to the revolutionary laws. This new law set a standard statutory closure period of 30 years for archives, but made provision for numerous exceptions: 120 years for medical records and personnel files; 100 years 


\section{2}

for legal proceedings, notary deeds, registry office records and documents containing personal data; and 60 years for documents "potentially compromising privacy" or relating to "state security and national defence".

It was then that the concept of "privacy" began to be recognised as an issue. According to the Senator tasked with defending the proposed legislation, the aim was "mainly to avoid premature disclosure of documents which, while not necessarily about individual private lives, may concern controversial issues or troubled times (French Occupation and Liberation) and documents that had related to national security". Since then, the notion of "protecting individual privacy" has been used as an excuse to prevent disclosure of information about crimes committed under the Occupation or during the colonial wars. To protect the "privacy" of the perpetrators of these crimes or, where relevant, their descendants, documents that "reveal behaviour under conditions which, if known, could be damaging to those responsible for such behaviour" must not be made public. According to this rationale, the records showing that senior civil servant (and later government minister) Maurice Papon was guilty of complicity in crimes against humanity in Bordeaux in 1942 should have remained secret to "protect the privacy" of Papon and his family. The case brought against Papon that culminated in his conviction in 1998 was only possible because of an archivist who was prepared to flout the law and deliver documents to the son of a deportee who perished in a Nazi concentration camp (Slitinski, 1983; Conan, 1998). Other than the provisions in the laws on amnesty, there are absolutely no grounds for covering up unspeakable deeds on the pretext of "protecting the privacy" of the perpetrators and certainly not their descendants, who are in no way responsible for these acts. "Protecting privacy" cannot be used as justification for attempts by government to plaster over chapters of French history, be they acts perpetrated under the Occupation, cases of torture or assassinations carried out by members of the French armed forces during the Algerian War or terrorist crimes committed by members of the OAS. ${ }^{5}$

In 1995, the then French Prime Minister Edouard Balladur tasked Guy Braibant, an honorary member of the Council of State, with reviewing this law and formulating proposals. In the report that he submitted on 28 May 1996, he recommended a number of measures, which represented a real move towards more open archives. The bill of 15 July 2008, adopted under Nicolas Sarkozy, also seemed to be a step in the same direction but in fact merely created further barriers to archival access.

\section{“Sarkozy” Law of 15 July 2008}

This law professed to make immediate access to public archives the norm, a principle that echoed the law of Messidor Year II, but that was almost straightaway given the lie, because provision was made for number of statutory closure periods and for the notion of "permanent withholding" for 
"weapons of mass destruction" - including the poison gases used a century earlier in World War I! ${ }^{6}$ Most of the existing closure periods were curtailed, with those for registry office records and notary deeds, for example, reduced from 100 years to 75 , and those for records "relating to national defence, state security and public order" cut from 60 to 50 years. But this was not systematically the case because, in particular, some judicial police archives now have the same status as legal archives and thereby closure periods of 75 rather than 60 years. The law also upholds the rather vague notion of documents "transmission of which would infringe privacy" or that "contain an appraisal or value judgement on an individual that could cast him or her in a poor light". The result is that records are not released, and the crimes committed by individuals are not brought to light and exposed. And most importantly, further non-legislative impediments were established shortly afterwards, which we shall be examining at a later stage.

As with earlier legislation, individual waivers may be granted to the statutory closure periods. The process is long and complicated, with the result that different researchers may receive different responses. No justifications are provided, unless an appeal is lodged with the Committee for Access to Official Documents (CADA - Commission d'Accès aux Documents Administratifs). ${ }^{7}$ Individual waivers seem either designed to open potential avenues of research or as privileges granted on an individual basis, in contradiction with one of the founding principles of the French Republic by which all citizens should have equal public service access rights.

The 2008 law, which is still in force, represented modest progress but contained its own contradictions. Three years later, its application was further complicated by the general interministerial instruction, a non-legislative text issued on 30 November 2011 towards the end of Nicolas Sarkozy's regime, which ran counter to the law by enabling authorities issuing documents marked "secret" to prevent their circulation by refusing to declassify them. When documents are stamped "secret" or "top secret", regardless of the date or subject concerned, archivists are obliged to request the issuing authority to declassify them, a process that has to be carried out for individual documents one by one (Veyssiere, 2019). In the meantime, archivists are required to put the documents in a sealed envelope bearing details of the disciplinary and professional sanctions or court sentences imposable on those found guilty of "compromising national military secrecy", researchers and archivists also running the risk of being barred from their professions. ${ }^{8}$ Attaching lasting importance to the "secret" stamp whenever it appears on a document - even though during the colonial wars it was sometimes added by superior officers to cover up the use of torture by their subordinates gives the French armed forces an excuse for not making documents available. In practice, it deprives victims' families and researchers of the chance to garner information on blatant abuses of human rights perpetrated during the colonial wars, particularly as a decree dated 2 December 2019 requires even stricter application of this 2011 interministerial instruction. ${ }^{9}$ 
In February 2020, in reaction to the "new impediment to research" (Vaïsse, 2019) represented by the general interministerial instruction of 30 November 2011, further aggravated by the decree of 2 December 2019 making its application even more stringent, the Association of French Archivists (AAF - Association des Archivistes Français) spoke up against the obligation incumbent on archivists to list "classified" documents and not pass them on to readers as they stand unless they have been declassified. ${ }^{10}$ The situation also sparked protests from numerous French and foreign researchers, with several thousand people signing a petition in this connection. ${ }^{11}$

\section{Archives of the colonial wars, including the Algerian War}

The archives of World War II, during which the Vichy Government and French institutions collaborated with the occupying Nazis, entered the public domain in their entirety on 8 May 2015, 70 years after the end of the war in Europe, following a class action from historians. A decree granting general exemption and enabling access to these archives was published on 24 December 2015 and implemented progressively in the corresponding archival institutions. However, many archives concerning the colonial wars during which human rights were violated by French law enforcement agencies had never been transferred or catalogued and consequently remained unavailable for consultation, even though their statutory closure periods had elapsed.

This led to strong demand for a general exemption to be decreed to provide open access to the archives of the Algerian War, along similar lines to the decree published in December 2015 for those of World War II. On 13 September 2018, during a visit to Josette Audin, the widow of Maurice Audin (a young mathematician and member of the Algerian communist party fighting for Algerian independence alongside the FLN) ${ }^{12}$, French President Emmanuel Macron published a statement acknowledging that her husband had been killed in Algiers in June 1957 by the troops who had taken him prisoner and that his death had been made possible by a system empowering the army to arrest all potential suspects. ${ }^{13}$ Yet thousands of other people lost their lives as a result of this system. The authorities also turned a blind eye to the torture inflicted by the army when interrogating and terrorising its prisoners. As Josette Audin wrote to Pierre Vidal-Naquet in September 1957, just a few weeks after her husband's disappearance and as he mentioned in his Mémoires, ${ }^{14}$ the vast majority of those abducted leaving their families without news were indigenous Algerians.

At this juncture, a few background details would perhaps not go amiss. During the first half of the 20th century, Algeria was considered an integral part of France and divided into départements. The Algerian War of Independence began on 1 November 1954 with a series of attacks organised by the FLN, which immediately set up groups of National Liberation Army (ALN - Armée de Libération Nationale) guerrillas throughout the country. 
A state of emergency was officially declared by law on 3 April 1955, conferring two powers on the French army which remained in place throughout the war: firstly, the right to arrest and detain suspects arbitrarily and, secondly, the right to try them in the military courts. In spring 1956, the French parliament voted to grant the "special powers" requested by Guy Mollet's Government, whereupon, in January 1957, the army was empowered to police the Algiers region. It arrested, interrogated and held people as it saw fit as part of a violent crackdown targeting not only the FLN-ALN fighters who were forming guerrilla groups and organising attacks, but also the members and supporters of the Algerian pro-independence parties, such as Messali Hadj's ${ }^{15}$ MNA,${ }^{16}$ or those joining it, the UDMA, ${ }^{17}$ the Ulamas ${ }^{18}$ and the PCA,${ }^{19}$ and any of their suspected supporters. Also targeted were all those belonging to networks involved in fundraising, promoting or providing logistics support for the guerrillas, plus anyone suspected of having sheltered or assisted militant nationalists. The first half of 1957 saw the "Battle of Algiers", which marked the climax of the "wholesale crackdown" operated by the security forces, intelligence services and French police, which targeted far more than just members of the organizations involved in the war, the maquis fighters and the perpetrators of attacks. It was during this dissuasive terror campaign, designed not only to stamp out enemy organizations but also to cut its fighters off from all sources of support, that Maurice Audin disappeared in June 1957. Torture followed by widespread enforced disappearances, not to mention other crimes such as rape, were commonplace under what was effectively a reign of terror.

In the absence of individual files on persons "reported missing" or archive collections providing full details of disappearances, and with records being, at best, scattered over different locations and, at worst, containing forgeries such as the documents fabricated to substantiate the fiction of Maurice Audin's escape ${ }^{20}$ researchers, beginning with Pierre Vidal-Naquet (1972), opted to focus on analysing the military rationale and workings of the system of repression (Thénault, 2004; Branche, 2005, pp. 213-217). Their account of the rationale applied during the Algerian War documented the so-called arrest and detention system (Thénault, 2013) roundly criticised by Emmanuel Macron in his presidential declaration of September 2018. ${ }^{21}$

But this declaration begs the further question of whether France can admit that Maurice Audin was held, tortured and assassinated by members of the French armed forces, while continuing to remain silent about the thousands of others who suffered the same fate. It has a responsibility to give the families of all these missing people access to any documents in the public archives that could shed light on their disappearances. This responsibility is even greater when the disappearances were caused by military or civilian personnel acting under the authority of the state. A seminar was organised on 20 September 2019, under the auspices of the National Consultative Committee on Human Rights (CNCDH - Commission Nationale Consultative des Droits de l'Homme) and supported by the major French 
human rights and anti-torture organizations, ${ }^{22}$ during which emphasis was placed on the enormous progress made in recent decades in international law with regard to enforced disappearances. All victims of such disappearances, wherever they are in the world, should now benefit from the "Joinet principles" officially recognised by the United Nations, and which consist of truth, justice and reparation. But for this, access to archives is vital.

In the wake of Emmanuel Macron's declaration, and with the support of various associations, Malika Rahal and Fabrice Riceputi and a number of other historians ${ }^{23}$ set up a website called 1000autres.org, in order to put names and faces of the many people who went missing during the Battle of Algiers, Algerians whose identities were until then, for the most part, unknown. As Fabrice Riceputi (2020) explained during the seminar, although army archives may offer little written information about this "arrest and detention" system, indirect evidence is obtainable from civilian archives. The website was in fact created after Riceputi had consulted a record at the French National Overseas Archives (ANOM - Archives Nationales d'Outre-mer) in January 2018 originating in the Algiers Prefecture and documenting the cases of some 850 Algerians arrested by the armed forces in Algiers in 1957.24 This record provides the full names and addresses of the individuals concerned, their professions and the precise circumstances of their arrest. It also indicates that, when questioned by Prefecture officials at the request of their families regarding the fate of these detainees, the 10th Parachute Division of the French army had, in the vast majority of cases, been unable or was unprepared to provide answers. In 1958, the Secretary General of the Prefecture, Paul Teitgen, had informed Pierre Vidal-Naquet that the Algiers Prefecture was compiling a file of this type. In addition, in May 1957, also acting on information from Paul Teitgen, Maurice Garçon, a lawyer and the Secretary General of the Commission for the Protection of Human Rights and Fundamental Freedoms (Commission de sauvegarde des droits et libertés individuels) requested access to this material, only to be brushed off with a categorical refusal. What did this file contain? Almost as soon as the police's powers were transferred to General Massu's 10th Parachute Division on 7 January 1957, the Algiers Prefecture, the Minister Robert Lacoste, the Attorney General Jean Reliquet and the military authorities began to receive reports of missing persons from lawyers and families, who knew exactly who was to blame, namely the law enforcement agencies and, in most cases, the army. Reports came from people who had no news of their relatives and were very worried, because like everyone else in Algiers at the time, they were perfectly aware that the army was torturing and spiriting away its detainees more or less clandestinely in dozens of different places. To respond to these enquiries, on 23 February 1957, Pierre Bolotte, Head of Cabinet to Serge Baret, IGAME ${ }^{25}$ Prefect of Algiers, tasked one of his agencies, the North African Liaison Department (SLNA Service des Liaisons Nord-Africaines), with collecting them together for referral to the appropriate authorities, the intelligence services and the 10th 
Parachute Division, as "requests for information about missing persons from their next-of-kin".

A few weeks later, the head of SLNA estimated that "fewer than a third of the families concerned were daring to contact" him over missing relatives detained by the armed forces of whom they were without news. Despite this, in the first two months, he still managed to collect 500 reports. According to the last statistics on record, by the end of 1958 no less than 2,039 reports had been received by his department, mostly relating to arrests in 1957 . But only the first 850 of these missing persons' reports still remain in the ANOM today. Some months later, this same department head was forced to admit that, in $70 \%$ of cases, either the army failed to respond, or its replies were, in his view, "inadequate" or "not valid". ${ }^{26}$ These 850 records form the basis for the 1000autres.org database. They do not constitute a complete list of persons reported missing and/or known to have died. The database contains a few well-known examples, not least those of Maurice Audin and Henri Alleg ${ }^{27}$ whose disappearances were rapidly reported to the SLNA by their wives, and Djamila Bouhired, who was reported missing by her lawyer Jacques Vergès. The majority, though, are unknown quantities. What happened to them after they were arrested? This is the question asked on the 1000autres.org website in its appeal for information. It is therefore a search tool in the most literal sense of the term. For who other than their friends, families and descendants can identify the people concerned?

Other written evidence tends to confirm that those reported missing were in fact dead, because several years later families were still appealing in the press for news of 1957 arrestees. The four main sources are, firstly, a brochure entitled Le Cahier Vert published by Nils Andersson's La Cité in 1959 containing some 175 reports of missing persons collected in August of that same year in Algiers by lawyers Maurice Courrégé, Michel Zavrian and Jacques Vergès. Virtually all date from 1957. In his postscript to this document, Pierre Vidal-Naquet was quick to describe the system of enforced disappearances operated by the French armed forces ${ }^{28}$ (Vergès, Zavrian, Courrégé, 1959, p. 52). Another source is the many letters reporting disappearances, at times accompanied by records of the internal investigations conducted by the armed forces, sent to the civilian and military authorities, which are now scattered across various collections: at the SHD, the ANOM, the French National Archives, particularly in the archives of the President of the Republic, who frequently received and continues to receive numerous enquiries, and the International Red Cross (ICRC). But none are specifically catalogued as relating to missing persons. Lastly, there are the archives of the two Commissions for the Protection of Human Rights and Fundamental Freedoms that were successively in operation from May 1957 until 1962, recording numerous instances of abuse and enforced disappearances, many of which relate to Algiers and to 1957 . These bulky records are now kept at France's National Archives ${ }^{29}$ and include numerous "individual files" unfortunately still partially classed as "secret" in 2019. For 171 cases, 
the members of these Commissions admitted that the individuals concerned were no longer alive but were unable to explain how they had died. These archives also contain a series of named records for almost 2,000 missing persons, a mixture of Algerians and extremist European activists, ${ }^{30}$ whose disappearances were reported at different stages of the war, in Algeria and in France. In principle, each record corresponds to a file on an investigation mandated by the Commission.

A final point worth mentioning concerns the appeals for information about missing persons published in the Algerian press, in Al Chaab and Alger Républicain, as of September 1962, in other words, following the release of camp and prison detainees. These were analysed by Malika Rahal and enabled some 300 further names to be added to the SLNA database used for the 1000autres.org website. But this does not answer Jules Roy's essential question, a question that has haunted thousands of families for over 60 years: "The thousands of others . . ., where are they?" Needless to say, none of the sources described previously provides even the slightest answer to this gruesome question. It should not be forgotten that, in those rare cases where disappearances were reported to the police, the investigations carried out were summary to say the least, and the files on them subsequently unceremoniously cancelled by the French Government in what amounted to self-amnesty in $1962 .{ }^{31}$ For their part, the enquiries conducted by the Commissions for Protection always subscribed to the military versions of events designed to obfuscate what really happened to those reported missing. Nevertheless, the website 1000 autres.org is slowly but surely bringing a substantial number of victims of enforced disappearances out of colonial obscurity.

By consulting other records and archives, it should be possible to document further missing persons' cases. The records of the International Committee of the Red Cross (ICRC) are a particularly promising source of information, as was explained by Daniel Palmieri, the organization's head of historical research, at the seminar mentioned previously. ${ }^{32} \mathrm{He}$ informed the assembled gathering that ICRC inspections carried out between February 1955 and March 1962 at several hundred detention centres in Algeria had culminated in some 1,000 investigations, the files which are freely consultable at the ICRC's archives in Geneva, including those marked "secret", "highly confidential", "private" or "for internal use only".

Little by little steps began to be taken under François Hollande's presidency (2012-2017) $)^{33}$ towards making French archives for this period freely accessible. On 19 March 2016, President Hollande even hinted that all archives should become part of the public domain: "Since 2008, our archives for this period have for the most part been openly accessible but, let me say here and now, that every single one of them should be accessible and available for consultation by the public at large". This text no longer features on the French Government website. Much still remains to be done and, as we have seen, there are now new obstacles threatening this fledgling 
process. Following Emmanuel Macron's declaration in September 2018, an order was published in the Official Gazette of 10 September 2019, ${ }^{34}$ but this only concerned a series of documents about the Audin affair - including some forged by the armed forces - that had already been brought to his family's knowledge several years before. It is other records that are more likely to shed light on the reasons why Maurice Audin was assassinated. For this, much more extensive measures will be needed to make all the archives for this period accessible on a blanket basis, rather than just those handpicked by the French Government for transmission to the families or for consultation by historians. ${ }^{35}$ Surely, it should be the State's role to afford historians liberal access to the archives for the period, so that they can freely consult the fonds they consider useful for their research, rather than "steering" them in a specific direction by making its own selection? And, as we have seen, the decree of December 2019 tightening up application of the provisions governing national military secrecy imposes more stringent or longer periods of secrecy and is therefore a backwards step. ${ }^{36}$

Researchers need to be given full access to all the archives from this period. It is also high time that the rule of silence maintained by the armed forces since the time of the Algerian War with regard to these events should cease, as suggested by Emmanuel Macron in his declaration on 13 September 2018. Leading figures in government and the armed forces should appeal to the French military personnel of the time to recount their experiences and deposit any material in their possession in the archives.

\section{What scope for a general exemption?}

A second general exemption covering "all those reported missing during the Algerian War" was announced on 13 September 2018 in the President's statement on the Audin affair. This was to follow on from the order specific to the case of Maurice Audin mentioned earlier. Thousands of Algerian families are now hoping that this will enable them to obtain information about those who, like Maurice Audin, went missing through acts perpetrated by the French law enforcement agencies. There were other individuals who went missing during this war: indigenous Algerians, at the hands of some of the leaders of the FLN-ALN or because of in-fighting between Algerian nationalists; French military personnel; and European Algerians, at different stages in the war, in particular after 18 March 1962 for, though the war between FLN-ALN and France was officially over, there were still armed confrontations, as the OAS refused either to accept the ceasefire and Algerian independence or to lay down its arms. For example, on or around 5 July 1962, a large number of European civilians disappeared in the Oran region never to reappear. The families of all those who disappeared involuntarily during the Algerian War are entitled to the same rights. But the only official action taken to date relates to French military personnel and European Algerians and, to a lesser extent, 
harkis. ${ }^{37}$ Yet, historically, commemoratively, legally and archivally, France is directly implicated in relation to those who disappeared through action on the part of French law enforcement agencies acting under the auspices of the State.

In 2004, to enable the families of European civilians who disappeared during the war or the months that followed to pick up their trace, the management of the French National Archives decided to allow them access to the files drawn up by the French authorities following the Evian Accords ${ }^{38}$ (Liskenne, 2015). On 1 July 2004, the archive department at the Ministry of Foreign Affairs embarked on an inventory of its records on people "missing and/or presumed dead in Algeria during the final months of French rule (1962)". Efforts were made to locate these records and two officers seconded to the department for the purpose of creating a detailed database for subsequent uploading to the Ministry's website. ${ }^{39}$ The inter-ministerial task force for repatriates and the repatriates' associations also stepped in to ensure that the families and heirs of missing persons obtained access to this material. Commemorative measures were belatedly taken for the harkis, who mostly disappeared after Algerian independence. Nothing of this kind has been done for the native Algerians who disappeared at the hands of the French law enforcement agencies.

One example was quoted by Chloé Leprince, a journalist at France Culture, following the seminar at the National Assembly. The children of Moktar Boucif, a headmaster in Thiersville (Mascara region) and a member of the Algerian pro-independence communist party, know nothing about the circumstances leading up to their father's arrest in April 1958 and his subsequent death. Senouci Boucif, then aged 7 but now retired, recalls his father being roughly arrested at about 2 o'clock in the morning and has an enduring memory of seeing him behind barbed wire fencing at the barracks where the family had heard he was being held. A book published in 2017 accuses Boucif of having masterminded, just before his arrest, the "despicable assassination" of Félix Vallat, pied-noir ${ }^{40}$ mayor of Thiersville, where Boucif was a headmaster (Alonso, 2017). By virtue of the exemption, the mayor's three sons are entitled to have access to the archives relating to the circumstances of their parents' murder but Moktar Boucif's children have no such right to consult the records of their father's incarceration and subsequent assassination (Leprince, 2019). Such double standards with regard to access to archives in a Republic that condemns discrimination and claims to have learned from the errors of the past can only be described as outrageous.

There is clearly every reason to consider creating an information office at military archives for families looking for records about their relatives, similar to that successfully established at the French National Archives for Europeans reported missing. All too often, families struggle because of the language barrier and the difficulties inherent in archival searches. But public archives are there to serve all citizens, regardless of nationality, who may be 
interested in consulting them. A department could be set up to assist those seeking information about the atrocities committed by the law enforcement agencies, finally acknowledged by the French President in 2018. ${ }^{41}$

Moreover, in cases where records have been destroyed, like some of those relating to the crackdown on the October 1961 demonstrations in Paris, special efforts could be made to cross-reference existing documents and flag up any missing elements. The guide to research on those who went missing during the Algerian War published by French National Archives in March 2020 could be extended to include this information, or to list fonds where duplicates may exist to complete the picture. ${ }^{42}$

\section{Need for a general exemption extending to all archives of the era}

For the colonial wars, Emmanuel Macron's most recent decision following the order of 9 September 2019 authorising access to archives regarding the disappearance of Maurice Audin should also apply to all persons reported missing during the Algerian War and to all public records for that period. As with the previous order concerning World War II, this principle should extend to documents from the post-war period. The 2015 inter-ministerial order on World War II concerns archives up to the end of the 1950s where these deal with attempts to cover up information about collaboration during the German Occupation. For the Algerian War, the period concerned would need to extend at least up to the 1968 amnesty laws, ${ }^{43}$ which would mean that the limit for consulting documents would extend back 52 years. This is consistent with the 50 -year statutory closure period stipulated in the 2008 legislation and would make court files immediately accessible.

There is probably information in the archives that researchers could access using their own techniques and methods to track down people who went missing during the Algerian War for reasons ascribable to the French law enforcement agencies. But, for this, they would need to enjoy the broadest possible access to the war archives, because the rare missing persons' records available cannot possibly hope to suffice. Access to all the archives from the period, and especially the records of internment camps and detainee sorting centres, prisoner detention records, military units' operations diaries, etc., is therefore vital.

There can surely be no reason why France should not allow very extensive, if not full, access to its Algerian War archives. A good 58 years after the end of the war, surely enough time has elapsed for an objective analysis to be made of the history of this period? Today there remain a few survivors, some of whom would still be able to recount their experiences and put a more realistic slant on archives often doctored or deliberately designed to mislead, those regarding Maurice Audin being a case in point. 


\section{A crucial civic issue for France and beyond}

Military secrecy and the fundamental interests of the State cannot be allowed to override human and citizens' rights. Archivists should not have to emulate Brigitte Laîné and bend the law in order to uphold their professional codes of conduct and defend human rights. Having given evidence in 1999 in support of Jean-Luc Einaudi, who was being sued by Maurice Papon over the existence of archives on the crackdown on Algerian demonstrations in Paris on 17 October 1961, this courageous archivist was then hauled over the coals and unfairly sanctioned by her hierarchy. To quote Jean-Yves Mollier (2018), "not only was she the chief heritage archivist at Paris Archives that many of us knew so well, but she was also a sort of latter-day Antigone".

The issues at stake not only concern our knowledge of a period of contemporary French history but are also vital to civil society. They are not unconnected with the political and sectarian forces in France that feed on the silences of the past and on history's refusal to face the truth about the colonial period. Making archives openly accessible will not only help defuse the tensions inherent in teaching colonial history but is also one of the prerequisites for present and future citizens to be able to share a common and dispassionate awareness of the past. It would also be a useful lesson for citizens in general, not just in France and Algeria but also those in all other places in the world.

On 21 June 2020, the Association of French Archivists, the French Association of Contemporary Historians in Higher Education and Research (AHCESR - Association des historiens contemporanéistes de l'enseignement supérieur et de la recherche) and the Josette \& Maurice Audin Association wrote to the Prime Minister urging that he remove the obstacles to access to pre-1970 French archives, in particular those relating to the Algerian War, which placed the administrative documents in contradiction with the letter of the law. They had already decided that, if the Prime Minister failed to respond positively to their request, they would lodge an appeal with the Council of State, demanding that the provisions in these texts interfering with the freedom to conduct research be rescinded. Readers with sufficient knowledge of French may like to take a look at François Demerliac's documentary "Après l'affaire Audin. Les disparus et les archives de la guerre d'Algérie" (What followed the Audin affair: missing persons and archives of the Algerian War), available online on the websites of the Algerian Cultural Centre in Paris (Centre culturel algérien de Paris) and the Colonial and Postcolonial History Association (Association histoire coloniale et postcoloniale) https://histoirecoloniale.net/Le-film-Apres-l-affaire-AudinLes-disparus-et-les-archives-de-la-guerre-d.html. This documentary offers an overview of the problems that have arisen with regard to this particular issue in the two years since the statement made by the French President on 13 September 2018. 


\section{Notes}

1 The idea of "public archives" stems from the 1789 Declaration of the Rights of Man, Article 15 of which states that: "Society has the right to require of every public agent an account of his administration".

2 The law of 24 June 1794 (7 Messidor Year II) stipulates (Article 37) that "All citizens may, on the prescribed dates and times, require all repositories to afford them access to the documents in their possession".

3 In contrast to the revolutionary law of 7 Messidor Year II, passed a century earlier, reference to which was actually struck out of the original copy of the decree of 12 January 1898 on the French National Archives (see the facsimile of the original in 1979. Genèse d'une loi sur les archives, Comité d'histoire du ministère de la Culture, La Documentation française, 2019, p. 73).

4 The laws of September 1790, June 1794 and October 1796.

5 The OAS (Organisation de l'Armée Secrète - Secret Army Organization) was an undercover organization created in 1961 to oppose Algerian independence.

6 Article L 213-2. II. Public archives may not be made available for consultation if they contain information that could facilitate the design, manufacture, use or location of nuclear, biological or chemical weapons, or any other weapons with direct or indirect effects capable of causing similar levels of destruction (French version available on the Légifrance website. Available at www.legifrance.gouv.fr/ affichTexte.do?cidTexte=JORFTEXT000019198529\&categorieLien=id).

7 Appeals may be lodged with the CADA, by those to whom an authority refuses to make available documents kept in the public archives, the CADA's opinion not, however, being binding. If the authority maintains its decision, those concerned may refer their case to the administrative courts.

8 IGI 1300 issued in 2011, Article 66, pp. 50-51 (available for consultation in French on the Légifrance website. Available at www.legifrance.gouv.fr/ affichTexte.do?cidTexte=JORFTEXT000024892134\&categorieLien=id. Under the Penal Code, anyone found guilty of "compromising national military secrecy" shall be liable for up to five years of imprisonment, a fine of 75,000 euros and, in the specific case of archivists, banned from exercising their profession ("the activity in the exercise or on the occasion of which the offence was committed", in the words of the text).

9 Available at www.legifrance.gouv.fr/eli/decret/2019/12/2/PRMD1928053D/jo/.

10 See the declaration by the Association of French Archivists: "Le "crépuscule des archives" ? Entre accès restreint pour les citoyens et contraintes professionnelles pour les archivistes " www.archivistes.org/Le-crepuscule-des-archives-Entreacces-restreint-pour-les-citoyens-et (in French only).

11 The protests of French and foreign historians were published in the daily newspaper Le Monde, on 14 February 2020. Available at www.lemonde.fr/idees/ article/2020/02/13/nous-denoncons-une-restriction-sans-precedent-de-l-accesaux-archives-contemporaines-de-la-nation_6029398_3232.html. Concurrently, Mediapart, published an article. Available at https://blogs.mediapart.fr/gillesmanceron/blog/130220/secret-defense-contre-l-histoire-fermeture-des-archivesdes-repressions-coloniales, and a petition was launched. Available at http://chng. it/qGrqBBbZ.

12 Front de Libération Nationale, a political party that supported Algerian independence.

13 Available at www.elysee.fr/emmanuel-macron/2018/09/13/declaration-dupresident-de-la-republique-sur-la-mort-de-maurice-audin.

14 "In this letter, written in early September, Josette Audin emphasised that her husband's case was nothing unusual, for Algerian Muslims were disappearing every day.” (Vidal-Naquet 1998, p. 61). 
15 An Algerian politician who played a pioneering role in the process that culminated in independence.

16 National Algerian movement.

17 The Union Démocratique du Manifeste Algérien "Democratic Union of the Algerian Manifesto" was an Algerian political party created by Ferhat Abbas in 1946.

18 Algerian religious association created in 1933.

19 Algerian communist party.

20 Gendarmerie reports of "prisoners shot while trying to escape" often provided the legal justification for summary executions.

21 Available at www.elysee.fr/emmanuel-macron/2018/09/13/declaration-du-president-de-la-republique-sur-la-mort-de-maurice-audin (in French only).

22 At the French National Assembly, on the subject of "Missing persons who disappeared during the Algerian War at the hands of the French law enforcement agencies: truth and justice?”, the videos of which have been published at https:// histoirecoloniale.net/Les-video-de-la-journee-du-20-septembre-2019-sur-les-disparus-de-la-guerre-d.html and proceedings at https://journals.openedition.org/ revdh/8447? file=1 (in French only).

23 Malika Rahal, historian, Institut d'histoire du temps présent (IHTP-CNRS), and Fabrice Riceputi, lecturer and historian, author of La bataille d'Einaudi, comment la mémoire du 17 octobre 1961 revint à la République, Le passager clandestin, 2015.

24 ANOM, 91/ 4 I 62, “Arrests, requests for investigations passed to military command".

25 From 1948 to 1964, IGAMEs were prefects of départements at the centre of military regions tasked with coordinating the action of the civilian and military authorities during periods of unrest.

26 For more information about this SLNA file, see: Riceputi, Fabrice. Histoire d'un fichier secret, la recherche des personnes enlevées par l'armée française à Alger en 1957. Available at http://1000autres.org/sample-page.

27 Harry Salem aka Henri Alleg (born on 20 July 1921 in London and died on 17 July 2013 in Paris), was the editor of the Alger Républicain newspaper, which was banned in 1955, and a member of the PCA. Detained on 12 June 1957, the day after Maurice Audin was arrested, he was also locked up and tortured. He later wrote an account of his ordeal, smuggling it out of prison via his lawyers. Published under the title La Question in February 1958, it was immediately banned, only to be reprinted in Switzerland with a preface by Jean-Paul Sartre. It was received with considerable acclaim.

28 A first list was published by Les Temps Modernes, no. 163, in September 1959.

29 French National Archives, Archives of the Commission for the Protection of Human Rights and Fundamental Freedoms (F/60/3124-F/60/3231).

30 Groups of European Algerians who, from the start of the war, staged armed attacks on the local population and, in early 1961, joined forces to create the Organisation de l'Armée Secrète - Secret Army Organization.

31 The Evian Accords were signed on 18 March 1962 and, on 22 March 1962, the French Government published two decrees, one (Decree No. 62-327) amnestying "offences committed during the Algerian uprising", in execution of one of the provisions of the accords - in $\mathbb{S}$ ) of Part 1 on the "Conditions for and guarantees of self-determination" - and the other (Decree No. 60-328, published in the Official Gazette on 23 March, p. 3144), amnestying "offences committed as part of law and order operations during the Algerian uprising before 20 March 1962", although this was not a specific requirement. 
32 Available at https://histoirecoloniale.net/Les-video-de-la-journee-du-20-septembre-2019-sur-les-disparus-de-la-guerre-d.html (in French only).

33 Following François Hollande's election as President, the order dated 1 February 2013 established a general exemption for the consultation of public archives relating to the disappearance of Maurice Audin. This was published in the Official Gazette on 23 February 2013, p. 3096 (available for consultation online in French at Légifrance).

34 Official order of 9 September 2019 on open access to archives regarding the disappearance of Maurice Audin. Available at www.legifrance.gouv.fr/affichTexte. do?cidTexte=JORFTEXT000039070402\&categorieLien=id.

35 As President Hollande had done on three earlier occasions: firstly, in 2013, with regard to the assassination of Maurice Audin; secondly, with regard to the December 1952 assassination of the Tunisian trade unionist Ferhat Hached; thirdly, in October 2012, over the massacre of Senegalese riflemen at Thiaroye in December 1944.

36 Decree 2019-1271 of 2 December 2019 on the conditions for classifying and protecting national defence secrecy. Available at www.legifrance.gouv.fr/eli/ decret/2019/12/2/PRMD1928053D/jo/texte.

37 Harkis: generic term for native Muslim Algerians who served as auxiliaries in the French Army during the Algerian War.

38 Anne Liskenne (2015) explains how the French administration dedicated resources to documenting the disappearance of Europeans and keeping their families informed.

39 This detailed database, covering only Europeans missing and presumed dead, was put online in 2004: www.diplomatie.gouv.fr/fr/archives-diplomatiques/sorienter-dans-les-fonds-et-collections/etat-civil-et-genealogie/article/recherchede-personnes-disparues-en-algerie-pendant-les-derniers-mois-de-la (in French).

40 The term "pieds-noirs" refers to French nationals born in Algeria and French nationals of other European origins who lived in French North Africa up until independence.

41 The office set up at the French National Archives in 2004 and acting as an intermediary for all those seeking to assert their rights (such as French Jews plundered or interned, and people wishing to obtain French nationality) could possibly handle this type of requests. (Editor's note).

42 This digital guide to the missing of the Algerian War lists archives according to the category of missing person and not to where the records are conserved. Available at https://francearchives.fr/actualite/223693824/.

43 Two amnesty laws were adopted in France, by virtue of which it is impossible to prosecute members of the armed forces for human rights violations perpetrated during the Algerian War. The first followed the Evian Accords and dates back to March 1962. This ruled out the possibility of prosecuting military personnel accused of violations during combat (and also amnestied Algerian independentists but not French nationals accused of providing support for the FLN, to whom amnesty was only extended in 1966). This law effectively prevented the terrorist actions of those in favour of pursuing the combat from escalating into Civil War in France. It is therefore part of the next chapter of the country's history and cannot be challenged in the same way as some Latin American amnesty laws. A second law came into force in 1968, granting full impunity to members of the French armed forces who had failed to obey the government's orders. In 1982, these two amnesty laws were further reinforced with the introduction of administrative measures. By contrast with South African Truth and Reconciliation process, where full disclosure on the part of those responsible for human rights violations under apartheid was the condition sine qua non for avoiding 
prosecution, these two amnesty laws and the 1982 measures officially granted impunity to perpetrators of violations and decreed that their crimes should be forgotten. Rather than persisting in denying the truth of the past, thereby leaving a gaping hole in the nation's memory, France would be well advised to seek inspiration from the concept of transitional justice which, according to French magistrate Louis Joinet in his Report to the United Nations in support of the combat against impunity for perpetrators of human rights violations, is part and parcel of "the right to know the truth and, its corollary, the duty to preserve memory" and to find specific ways of lifting the veil of silence and official forgetfulness cloaking this chapter of history, this having a detrimental effect on the country today.

\section{Bibliography}

Alonso, Maïa. 2017, Le rêve assassiné. Lyon: Editions Atlantis.

Branche, Raphaëlle. 2005, La guerre d'Algérie: Une histoire apaisée? Paris: Seuil.

Conan, Eric. 1998, Le procès Papon: Un journal d'audience. Paris: Gallimard.

Leprince, Chloé. 2019, Guerre d'Algérie: Quand le secret défense entrave la mémoire. Article published on 14 October, France Culture website. Available at www.franceculture.fr/histoire/guerre-dalgerie-quand-le-secret-defense-entrave-la-memoire.

Liskenne, Anne. 2015, "Les Français disparus en Algérie dans les archives du ministère des Affaires étrangères," La Gazette des Archives, vol. 239, pp. 21-30.

Mollier, Jean-Yves. 2018, "Hommage à Brigitte Laîné (1942-2018), une juste parmi les justes," Actualité du XIXe siècle, Journal on line of the Société d'histoire de la Révolution de 1848 et des révolutions du XIXe siècle, 19 November.

Riceputi, Fabrice. 2020, “Confronter les archives de l'État aux mémoires vives: le site de recherche de disparus 1000autres.org," Actes de la journée d'étude, "Les disparus de la guerre d'Algérie du fait des forces de l'ordre françaises: Vérité et Justice?" pp. 17-22. The CREDOF Website. Available at https://journals.openedition.org/revdh/8447? file $=1$.

Slitinski, Michel. 1983, L'affaire Papon. Paris: Editions Alain Moreau.

Thénault, Sylvie, rééd. 2004, Une drôle de justice: Les magistrats dans la guerre d'Algérie. Paris: La Découverte.

- 2013, “Justice et droit d'exception en guerre d'Algérie (1954-1962)," Les Cabiers de la Justice, vol. 2, no. 2, pp. 71, 81.

Vaïsse, Maurice. 2019, "Un historien face au secret des archives," 20 \& 21. Revue d'histoire, vol. 143, pp. 149-153.

Vergès, Jacques, Zavrian, Michel, and Courrege, Maurice. 1959, Les disparus, le "cahier vert”. Lausanne: La Cité-éditeur.

Veyssiere, Marion. 2019. "La communication des archives publiques en France. Le cadre législatif et réglementaire à l'épreuve de la pratique," 20ひ21, Revue d'histoire, vol. 142, pp. 141-149.

Vidal-Naquet, Pierre. 1972, La Raison d'État and La Torture dans la République. Paris: Minuit. 1998, Mémoires. 2. Le trouble et la lumière 1955-1998. Seuil: La Découverte. 